\title{
The Effect Of Parenting Training Strategies And Education Levels On Mother's Communication Ability
}

\author{
Adiyati Fathu Roshonah, Fasli Jalal and Elindra Yetti
}

\begin{abstract}
The purpose of this study was to determine the effect of parenting training strategies and level of education on mother's communication ability to children aged 4-5 years. The study used an experimental method with a $2 \times 2$ factorial design. The study sample was 34 mothers who had early childhood in DKI Jakarta Non-Formal Early Childhood Education. Parenting strategies for Problem Based Learning (PBL) and Experiential Learning (EL) training were carried out eight times in 90 minutes each meeting for two months. Higher education level that is high school. Low levels of education are the junior and elementary school. The results showed that the communication ability of parenting trainees in PBL strategies were higher than those of $E L$ parenting strategy participants. There was an interaction effect between parenting training strategies and education level on mother's communication ability. Communication ability of highly educated mothers were better through parenting PBL strategies and communication ability of low-educated mothers are better if they take part in EL parenting training. This study suggests that choice of a parenting training strategy needs to be adjusted to the level of education to produce good communication ability.
\end{abstract}

Keywords: Parenting Training, Education Level, Communication Ability

\section{INTRODUCTION}

Important communication ability possessed by parents. When a child develops, they need interaction with people who love them. Through good communication parents can build positive and pleasant relationships. Recent research suggests that children who grow up with good communication tend to have personality, resistance to stress and better self esteem compared to children who have bad relationships and communication with their parents. Hauser $\&$ Bowlds in Santrock $^{(1)}$ found that parents who use enabling behaviors such as explanation, acceptance and empathy will more facilitate the development of child identity than parents who use constraining behaviors such as judging and disparaging. Although everyone is considered to know how to communicate, in reality communicating is not always easy. For this reason education and communication training are needed ${ }^{(2)}$.

This fact is in line with the results of the research of Sumargi, et al. ${ }^{(3)}$ in 273 Indonesian parents living in Indonesia and Australia, which showed that many parents used ineffective parenting strategies such as shouting when facing unwanted child behavior. The results of other studies

Revised Manuscript Received on April 19, 2019.

Ir. Adiyati Fathu Roshonah, M.Pd., Early Childhood Education, Universitas Negeri Jakarta, Indonesia .

Prof. dr. Fasli Jalal, Ph.D., Pascasarjana Universitas Negeri Jakarta, Indonesia.

Dr. Elindra Yetti, M.Pd., Pascasarjana Universitas Negeri Jakarta, Indonesia. also revealed that family understanding and awareness of the importance of family communication is still relatively low. Many families have no restrictions and clear commitments regarding family communication so family communication is often only understood as a routine, not as something that has meaning for child development ${ }^{(4)}$.

Facing the above problems, parents in this case cannot just be blamed, but according to Gordon ${ }^{(5)}$, they need to be trained. In order to have good communication skills, knowledge and understanding are needed and training can be applied in the parenting process. Good communication ability can be obtained one of them through the learning process. Understanding parents about the importance of communicating and practicing communication ability is an important thing that can no longer be delayed to ensure optimal child growth and development. This effort is commonly known as parenting training, which is a program to change or improve childcare skills ${ }^{(6)}$.

In order for optimal learning goals to be achieved parenting training requires an andragogical strategy that must be adapted to its purpose and context, relevant to the actual and effective situation, meaning that it can connect the abilities received with the actual situation. Some choices include Experiential Learning (EL) and Problem Based Learning (PBL).

\section{LITERATURE REVIEW}

Communication ability are fundamental in parenting, but not everyone can communicate with great nature ${ }^{(2)}$. According to Cutlip, et al. ${ }^{(7)}$, factors that influence communication namely communicant ability, credibility, context, content, continuity and consistency and distribution channels. The communication process is influenced by several factors, namely the level of knowledge, development, perception, values, socio-cultural background, emotions, gender, roles and relationships, environment, and distance $^{(8)}$.

Communication skills are abilities or skills to communicate verbally and non-verbally to tell or to change attitudes, opinions, or behavior. The ability to communicate verbally includes speaking ability and listening ability. Speaking skills include openness, clarity, continuity / tracking, respect and supportiveness ${ }^{(9)}$, positiveness and positive talk ${ }^{(10)}$, equality or similarity, empathy ${ }^{(11)}$ and attention to time $\&$ relevance ${ }^{(12)}$. The ability to listening 
includes active listening and empathic listening ${ }^{(13)}$. The ability to communicate non-verbally includes tone of voice, touch, posture, eye contact or gaze, facial expressions and gestures $^{(14)}$. in human beings. Education is more directed at solving knowledge problems, while training is more directed at skill problems. Both are used together to solve motivation problems. Therefore the understanding of training strategies in this study refers to the understanding of learning strategies. Learning strategies have five components, namely Pre-Instructional Activities, Content Presentation, Learner Participation, Assessment and Follow-Through Activities $^{(15)}$.

Experiential Learning is a strategy in which it contains the process of constructing knowledge through transforming experiences. Learning from experience here includes the relationship between aspects of doing and thinking. According to Kolb in Bergsteiner ${ }^{(16)}$, a person will learn much better through his active involvement in the learning process. EL is described in a training cycle in a hierarchical manner at each stage. There are four stages of Concrete Experience, Positive Observation, Abstract Conceptualization, Active Experimentation ${ }^{(17)}$.

Problem Based Learning strategies provide learners the opportunity to explore problems and develop effective approaches to solving existing problems ${ }^{(18)}$. PBL characteristics: 1) Learning begins with problems and problem solving is the focus of the lesson, 2) Learners are responsible for designing strategies and finding solutions to problems, 3) Groups consist of 3 or 4 people so that all learners are involved in the process, 4) Facilitator guiding learner efforts with questions and other forms ${ }^{(19)}$.

\section{METHODOLOGY/MATERIALS}

This study uses an experimental method ${ }^{(20)}$, 2x2 treatment design by level ${ }^{(21)}$. Treatment variables are parenting training strategies namely problem based learning (A1) and experiential learning (A2) strategies. Moderator variables are mothers with high education (B1) and mothers with low education (B2). The dependent variable is the communication ability of mothers with children aged 4-5 years.

Parenting training strategies are ways to deliver parenting training material using adult learning (andragogy) that contains certain syntax or stages. This syntax is designed to make it easier for participants to understand the training material. It contains an action plan that contains a series of activities designed to achieve training objectives, contains components, such as the media used, methods chosen, organizing learning activities, use and management of time, classroom management and forms of evaluation used in assessing trainees .
Education and training are related to learning and changes

Table 1

Syntax of Parenting Training

Experiential Learning (EL) and Problem Based Learning (PBL) Strategies

\begin{tabular}{|c|c|}
\hline $\begin{array}{l}\text { EXPERIENTIAL } \\
\text { LEARNING }\end{array}$ & $\begin{array}{l}\text { PROBLEM BASED } \\
\text { LEARNING }\end{array}$ \\
\hline $\begin{array}{l}\text { FASE } 1 \\
\text { Opening }\end{array}$ & $\begin{array}{c}\text { FASE 1 } \\
\text { Identifying The } \\
\text { Problem }\end{array}$ \\
\hline $\begin{array}{c}\text { FASE } 2 \\
\text { CE/Concrete Experience }\end{array}$ & $\begin{array}{c}\text { FASE } 2 \\
\begin{array}{c}\text { Representing The } \\
\text { Problem }\end{array}\end{array}$ \\
\hline $\begin{array}{c}\text { FASE } 3 \\
\text { RO/Reflective } \\
\text { Observation }\end{array}$ & $\begin{array}{c}\text { FASE } 3 \\
\text { Selecting A Strategy }\end{array}$ \\
\hline $\begin{array}{c}\text { FASE } 4 \\
\text { AC/Abstract } \\
\text { Conceptualization }\end{array}$ & $\begin{array}{c}\text { FASE } 4 \\
\text { Implementing The } \\
\text { Strategy }\end{array}$ \\
\hline $\begin{array}{c}\text { FASE } 5 \\
\text { AE/Active } \\
\text { Experimentation }\end{array}$ & $\begin{array}{c}\text { FASE } 5 \\
\text { Evaluating The } \\
\text { Results }\end{array}$ \\
\hline CLOSING & CLOSING \\
\hline
\end{tabular}

Source: Modification of Kolb ${ }^{(22)}$, Eggen \& $\operatorname{Kauchak}^{(19)}$, Jonassen, et al. ${ }^{(18)}$ 


\section{RESULTS AND FINDINGS}

The results showed a significant difference in communication ability between parenting trainees in PBL strategies compared to parenting trainees in EL strategies. From the statistical data analysis, the results showed that overall the parenting communication ability of PBL strategies were better than those of parenting participants in EL strategy.

Problem-based instruction in parenting training PBL strategies was designed to provide opportunities to solve unstructured problems. It is from this problem solving and critical thinking activity that participants find answers related to the problems encountered in communicating with children, as stated in the Ramsay, et al. ${ }^{(23)}$, Tick ${ }^{(24)}$, Beringer $^{(25)}$ and Shamsan \& Syed ${ }^{(26)}$. Problems to be solved in PBL parenting strategy training are presented in the form of Communication Card Media, which consists of 8 sets namely Children's World Cards, Communication Barriers Cards, Children Name Cards, Popular Style Communicating Cards, Cards Naming Children's Feelings, Body Language Cards, Assertive Speaking Card and Active Listening Card. This Communication Card is distributed to each group at each meeting.

The direct involvement and activity of participants in the training process is what makes participants able to remember concepts longer, because learning that is more remembered is that which provides meaningful experiences and opportunities to be directly involved. This is what makes the communication ability produced in parenting training PBL strategies better than EL strategies.

Hypothesis testing shows that communication ability of highly educated participants are better than those with low education. As stated by Potter, et al. ${ }^{(8)}$, one of the factors that influence communication is the level of knowledge. The level of knowledge is closely related to the level of education. The higher the level of education, the easier they are to receive and develop knowledge and technology ${ }^{(27)}$. Parents who have higher education will find it easy to receive information sources ${ }^{(28)}$.

A person can convey messages easily if he has extensive knowledge. Mothers with high levels of education will find it easier to choose words or diction when communicating with children. Better knowledge will make it easier to manage and receive messages better. In addition, highly educated mothers have the ability to learn, practice and think higher. This makes it faster to master the ability to communicate with children.

Testing the hypothesis shows that there is an interaction effect between Parenting and Education Level Training Strategies on Mother's Communication Ability with children aged 4-5 years. The interaction effect is $55.66 \%$. In other words there were also influences outside of parenting training strategies and education levels that were not examined in this study, which also influenced the communication ability of mothers with early childhood

For Higher Education Mothers, Ability to Communicate better when participating in the Problem Based Learning (PBL) Parenting Training. This is because in the PBL parenting strategy training participants get the opportunity to hone high-level thinking skills, problem solving, discuss problem solving in groups and then present the results of the discussion in front of other groups. The opportunity to work collaboratively in groups is a challenge for trainees who are highly educated because this fits their learning needs. In addition, in the PBL parenting strategy training opportunities were found for critical thinking in problem solving. Mothers who are highly educated, in accordance with the results of previous studies ${ }^{(29)}$, generally are relatively more independent, more confident, more free from anxiety and other psychological problems, compared to mothers with low or uneducated education.

Really uneducated parents even have low emotional stability and a higher level of anxiety. The mothers with high education also have characteristics that are easier to obtain, access and process information than mothers with low education. With these characteristics they are easier to take part in the problem-based learning parenting strategy that enables them to pursue the goals of high-level thinking skills, such as the ability to analyze, synthesize or evaluate something. In addition to parenting training in PBL strategies, highly educated mothers will have the opportunity to develop their ability to discuss, exchange thoughts and be responsible for overall group performance. In this context if there are participants in the group who have less ability, then they are conditioned and responsible for teaching friends in their groups so that all group members have relatively the same abilities.

For Low Educated Mothers, Communication Ability is better when participating in Experiential Learning (EL) Parenting Strategies. Respondents with low levels of education in the context of this study were lower middle school (junior high, elementary or no school). In the EL parenting strategy training there are not specifically demands for high-level thinking and problem solving. In addition to the EL parenting strategy training there is also no demand in the group to discuss a case and present and present it to other groups. Low-educated mothers also have lower reasoning and catching power, which makes them have their own level of difficulty when faced with demands for problem solving in parenting training PBL strategies With this experience-based learning naturally, the limitations generally possessed by low-educated mothers such as lack of independence, lack of confidence and other anxiety can be neutralized. Low-educated mothers tend to feel more comfortable learning naturally by sharing experiences with fellow parents.

\section{CONCLUSION}

Based on the results of the research that has been done, it can be concluded that the communication ability of mothers with 4-5 year old children can be improved by parenting strategy problem based learning (PBL) if the mother's education level is high and can be improved by parenting training in experiential learning (EL) if mother's education level is low. There is an interaction effect between the parenting training strategy and education level on the communication skills of mothers with children 4-5 years at $55.66 \%$. This means that there are other factors outside of 
this study of $44.34 \%$ which are not examined which also influence the ability of mothers to communicate with children.

\section{ACKNOWLEDGMENT}

Sulfikar Sallu ID Scopus 57200989289 Lecturer at the Faculty of Information Technology, University Sembilanbelas November, Kolaka, Southeast Sulawesi, Indonesia.

\section{REFERENCES}

1. Santrock, J. W. Life-Span Development. New York : McGraw-Hill. 2006

2. Ruben, B.D. and Stewart, L.P. Communication and Human Behaviour. USA : Alyn and Bacon. 2005

3. Sumargi, A., Sofronoff, K., \& Morawska, A. Understanding Parenting Practices And Parents' Views Of Parenting Programs: A Survey Among Indonesian Parents Residing In Indonesia And Australia. Journal Of Child And Family Studies. Https://Doi.Org/10.1007/S10826-013-9821-3. 2013

4. Setyowati, Y. Pola Komunikasi Keluarga dan Perkembangan Emosi Anak (Studi Kasus Penerapan Pola Komunikasi Keluarga dan Pengaruhnya Terhadap Perkembangan Emosi Anak Pada Keluarga Jawa). Jurnal Ilmu Komunikasi Vol 2, No 1. 67-78. DOI: https://doi.org/ 10.24002/ jik.v2i1.253.

5. Gordon, T. Parent Effectiveness Training: The Proven Program for Raising Responsible. New York : Three Rivers Press. 2008

6. Bowman, S., Pratt, C., Rennekamp, D., \& Sektnan, M. Should We Invest In Parenting Education. The Ford Family Foundation's Enhancing The Skills Of Parents Program, Ii ..... 2010

7. Cutlip, S.M., Center, A.H., dan Broom, G.M. Effective Public Relations. Edisi Kesembilan. Jakarta: Kencana. 2011

8. Potter, P.A., Perry, A.G., Stockert, P., Hall, A. Fundamentals of Nursing. Ninth Edition. Missouri : Elsevier. 2017

9. Olson, D.H. Faces Iv and the Circumplex Model: Validation Study. Journal Of Marital And Family Therapy, 37(1), 64-80. 2011

10. Bloch, D., \& Merritt, J. The Power Of Positive Talk. Batam: Karisma Publishing Group. 2006

11. Devito, J.A. The Interpersonal Communication Book. London : Pearson. Https://Doi.Org/10.1037/026727. 2013

12. Purba, A. Pengantar Ilmu Komunikasi. Medan. Pustaka Bangsa Press. 2006

13. Essa, E. L. Introduction To Early Childhood Education. Cengage Learning. 2012

14. Ottenheimer, H.J. The Antropology of Language : An Introduction To Linguistic Anthropology. Kansas State : Thomson Wadsworth. 2007 of Instruction. University of Colorado Denver : Merril Pearson. 2009

16. Bergsteiner, H., Avery, G. C., \& Neumann, R. Kolb's Experiential Learning Model: Critique From A Modelling Perspective. Studies In Continuing Education.Https://Doi.Org/10.1080/ 01580370903534355.2010

17. Sharlanova, V. Experiential Learning. Trakia Journal Of Sciences, 2(4), 36-39. 2004

18. Jonassen, D. H., Howland, J., Moore, J., \& Marra, R. M. Learning To Solve Problems With Technology: A Constructivist Perspective. 2003
15. Dick, W., Carey, L., Carey, J.O. The Systematic Design

19. Eggen, P., \& Kauchak, D. Educational Psycology: Windows On Classrooms. 8th. Upper Saddle River, London : Pearson. 2001

20. Creswell, J. Research Design: Qualitative, Quantitative, And Mixed Method. Sage. Https://Doi.Org/10.2307/1523157. 2009

21. Gall, M. D., Borg, W. R., Gall, J. P. Applying Educational Research: How to Read, Do, and Use Research to Solve Problems of Practice, London Pearson. 2010

22. Kolb, D.A. Experiential Learning: Experience as the Source of Learning and Development. Pearson Education. 2015

23. Ramsay, J., Sorrell, E., \& Others. Problem-Based Learning An Adult-Education-Oriented Training Approach For Sh\&E Practitioners. Professional Safety, 52(09). 2007

24. Tick, A. Application of Problem-Based Learning in Classroom Activities and Multimedia. 5th SlovakianHungarian Joint Symposium On Applied Machine Intelligence And Informatics. 2007

25. Beringer, J. Application Of Problem Based Learning Through Research Investigation. Journal Of Geography In Higher Education. Https://Doi.Org/ 10.1080/03098260701514033. 2007

26. Shamsan, B., \& Syed, A. T. Evaluation Of Problem Based Learning Course At College Of Medicine, Qassim University. International Journal Of Health Sciences. 2009

27. Notoatmodjo, S. Pendidikan dan Perilaku Kesehatan Cetakan Pertama. Jakarta : Rineka Cipta. 2003

28. Apriastuti, D.A. Analisis Tingkat Pendidikan dan Pola Asuh Orang Tua dengan Perkembangan Anak Usia 48 60 Bulan. Bidan Prada: Jurnal Publikasi Kebidanan Akbid YLPP Purwokerto Vol 4, No 01. 2013

29. Parveen, A., \& Alam, M. T. Does Mothers' Education Influence Children's Personality Factors And Academic Achievement? Bulletin Of Education \& Research. 2008

\section{AUTHORS PROFILE}

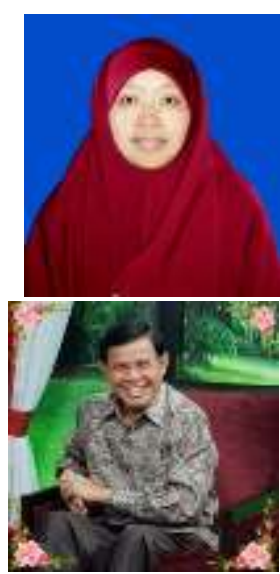

Adiyati Fathu Roshonah. Post-graduate students at Universitas Negeri Jakarta. Permanent lecturers at the Faculty of Education, Early Childhood Education Study Program at Universitas Muhammadiyah Jakarta

.Email : adiyati_fathu@mahasiswa.unj.ac.id

Fasli Jalal. Professor of Universitas Negeri Jakarta. Alumni of the Andalas University Medical Faculty and Cornell University. Initiator and figure of Indonesian early childhood education.।

Email : faslijalal@yahoo.com

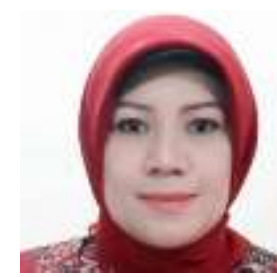

Elindra Yetti. Permanent lecturers at the Postgraduate Program in Jakarta State University. Coordinator of the Doctoral Program in the Early Childhood Education Study Program at Universitas Negeri Jakarta. Email : elindrayetti@unj.ac.id 